\title{
Nature of non-B, non-T lymphomas: an immunohistological study on frozen tissues using monoclonal antibodies
}

\author{
G PALLESEN, ${ }^{*}$ PCL BEVERLEY,† EB LANE,‡ M MADSEN,§ DY MASON,I H STEIN"
}

From the *University Institute of Pathology, University of Aarhus, Kommunehospitalet, Aarhus, Denmark, the †ICRF Human Tumour Immunology Unit, University College Hospital, London, the łImperial Cancer Research Fund, Lincoln's Inn Fields, London, the §Tissue Typing Laboratory, Blood Bank and Blood Grouping Laboratory, University of Aarhus, Kommunehospitalet, Aarhus, Denmark, the |Nuffield Department of Pathology, University of Oxford, John Radcliffe Hospital, Oxford, and the IInstitute of Pathology, Cristian Albrechts University, Kiel, West Germany

SUMMARY In a previous study employing conventional immunological marker analysis we found that $17 \%$ of high grade malignant lymphomas were devoid of cytoplasmic and membrane immunoglobulin and also sheep erythrocyte receptors. Cryostat sections from 24 of these cases (four of low grade and 20 of high grade malignancy) were stained with a panel of 30 monoclonal antibodies and six polyclonal antisera using a sensitive immunoperoxidase method. All tumours expressed the leucocyte common antigen (detected by monoclonal antibody 2D1) and all lacked epithelial cytokeratin (monoclonal antibody LE61), confirming their haematopoietic origin. All but one of the lymphomas expressed antigens characteristic of either B cells (17 cases) or T cells (six cases), while one case (morphologically a centroblastic lymphoma) had an unusual dual phenotype in which strong staining for T6 (marker of immature T cells) was associated with expression of the pan B lymphocyte antigens detectable with To15, anti-B1, anti-Leu12. This case was therefore classified as a B cell lymphoma showing aberrent expression of the T6 antigen. The pan B cell antibodies (To15, anti-B1, anti-Leu12) all appeared highly specific and sensitive, but the simultaneous use of all three monoclonal antibodies was necessary to detect the B cell nature in each of the 18 lymphomas. A wider panel of monoclonal antibodies was required to detect $\mathrm{T}$ lymphomas since these often disclosed atypical and restricted phenotypes. To15 and UCHT1 were the most reliable antibodies for the detection of B and T cell neoplasms, respectively. We conclude that most, if not all, "non-B, non-T" lymphomas are of either B or T lymphocyte origin and that monoclonal antibodies provide indispensable tools in their classification and diagnosis.

Non-Hodgkin's lymphomas which lack conventional $B$ and $T$ cell markers (cytoplasmic and surface membrane immunoglobulin and sheep erythrocyte receptors) constitute a major taxonomic challenge. In a previous study of marker expression in high grade lymphomas we found that $17 \%$ were "null" cases.' In several other series, however, the figure has exceeded $50 \% .^{2-4}$

Since the real nature of such null lymphomas remains obscure, the advent of monoclonal anti-

Accepted for publication 15 May 1984 bodies against lymphoid cell membrane antigens provides a new opportunity to characterise their origin in relation to their morphology.

We have adopted this approach in biopsy material from 24 non-B, non-T lymphomas using a panel of 30 monoclonal antibodies for staining cryostat sections by a sensitive immunoperoxidase method. This study showed that all tumours of this group were of either B or T lymphocyte lineage. This study also indicated the diagnostic importance of monoclonal antibodies in surgical pathology since several of these lymphomas had originally been diagnosed as anaplastic carcinomas. 
Table 1 Immune phenotypes (based on non-monoclonal markers) in 180 non-Hodgkin's lymphomas

\begin{tabular}{lllllll}
\hline & \multicolumn{5}{l}{ Immunological phenotype } \\
\cline { 2 - 7 } Morphology & $B$ & $T$ & $O$ & Total \\
\hline $\begin{array}{l}\text { Low grade } \\
\text { malignancy }\end{array}$ & $64\left(35^{*}\right)$ & 7 & $(4)$ & 5 & $(3)$ & $76(42)$ \\
$\begin{array}{c}\text { High grade } \\
\text { malignancy }\end{array}$ & $59(33)$ & $24 \dagger(13)$ & $21(12)$ & $104(58)$ \\
$T o t a l$ & $123(68)$ & 31 & $(17)$ & $26(15)$ & $180(100)$ \\
\hline
\end{tabular}

Cases included in this Table were collected over a five year period (1978-83) at Aarhus Kommunehospital and phenotyped primarily by conventional techniques applied to cell suspensions or cryostat tissue sections, or both.

* \% values are given in parentheses.

$\dagger$ Pleomorphic $T$ cell lymphoma $(n=9)$ was considered a lymphoma of high grade malignancy.

\section{Material and methods}

\section{SELECTION OF MATERIAL}

The material comprised frozen lymph node biopsy specimens from 24 patients. These had been selected from samples from 180 patients with nonHodgkin's lymphoma. The biopsies had been collected at the University Institute of Pathology, Aarhus Kommunehospital, by one of the authors (GP) during a five year period (1978-83). Cell suspensions or tissue cryostat sections, or both, from each biopsy had been investigated for the expression of surface membrane immunoglobulin and sheep erythrocyte receptors according to previously published methods.' Cytoplasmic immunoglobulin had been analysed in sections of formalin fixed paraffin embedded tissue following trypsinisation using either a peroxidase-antiperoxidase technique or a two step indirect immunoperoxidase method. Enzyme cytochemical stainings had also been performed on imprints from fresh biopsies in order to exclude myelocytic and monohistiocytic neoplasias.'

The 180 malignant lymphomas were morphologically classified according to the Kiel classification. Table 1 indicates the immunological phenotypes of the tumours in relation to the histological grade. The frozen material from two of the 26 non- $B$, non- $T$ lymphomas in Table 1 was of insufficient quality for the present immunohistological investigation.

\section{ANTIGENS AND MONOCLONAL ANTIBODIES Cytokeratin}

Antibody LE61 reacts with cytokeratin intermediate filaments in all benign and malignant epithelial tissues except squamous epithelium. ${ }^{5}$ A positive reaction precludes the possibility of haematopoietic tumour, including lymphoma.

Pan-leucocyte

Antibody 2D1 reacts with most haematopoietic cells (benign or malignant) except plasmacytes and some very immature lymphoblastic lymphomas, on which we have seen weak reactions. ${ }^{6}$ The antibody has not given positive results when extensively tested against non-haematopoietic tissues and tumours and is extremely valuable when used together with a broad spectrum antiepithelial antibody-for example, monoclonal antibody LE61-in the diagnosis of routine tumour biopsies (unpublished observations). ${ }^{7}$

\section{B lymphocyte associated}

Antibody ${\text { To } 15^{8}}$ reacts with an antigen expressed from very early in B cell differentiation but which is lost by the plasmacyte stage. Its distribution is similar to B1, but, unlike B1, it is not expressed in macrophages.

Anti-BI (Coulter Electronics) reacts with an antigen which is expressed from the early stages of $B$ cell differentiation but which is lost by the plasmacytes. ${ }^{9}$ Moderate cytoplasmic staining is often obtained in macrophages in tissue sections.

Leu12 (Becton-Dickinson) is an antigen detected by a newly developed pan-B lymphocyte antibody.

Antibody BA-1 (Hybritech) 10 reacts with an antigen with a more restricted occurrence since it is expressed by primary follicle and mantle zone B lymphocytes, but absent or only weakly expressed on germinal centre cells. Endothelial cells in the postcapillary venules are also strongly stained.

$T \ddot{1} 1$ reacts with an antigen restricted to $B$ lymphocytes of the primary follicle, the lymphocytic mantle zone, and partly to cells of the light zone of the follicular centre. Dentritic reticulum cells of the follicles stain strongly, and macrophages show weak expression of the antigen." This monoclonal antibody was a generous gift from $\operatorname{Dr} A$ Ziegler (Tübingen).

38.13 is a rat monoclonal antibody that recognises an antigen expressed primarily on endemic and non-endemic Burkitt's lymphoma cells. ${ }^{12}$ This antibody reacts strongly with dendritic reticulum cells, sinus lining cells, and endothelial cells in normal lymph nodes, but does not stain lymphocytes in benign lymph nodes. The antibody was a gift from Dr $M$ Fellous (Paris) and $\operatorname{Dr} J$ Zeuthen (Copenhagen).

\section{T lymphocyte associated}

Anti-Lyt3 (New England Nuclear) and OKT11 (Ortho Pharmaceuticals) both react with the $\mathrm{E}$ receptor of $\mathrm{T}$ lymphocytes. ${ }^{1314}$ In tissue sections, however, they also give cytoplasmic staining of many macrophages (including histiocytosis $X$ cells) and of some Hodgkin's and Reed-Sternberg cells. Anti-Lyt3 (=antibody 9.6) produces a more intense and clearer staining than OKT11. 
Anti-Lyt2 (New Éngland Nuclear) ${ }^{15}$ and Tü71 (Dr A Ziegler) react with a glycoprotein expressed by most $\mathrm{T}$ lymphocytes and by chronic lymphatic leukaemia cells of B type. This antigen is also detected by antibodies OKT1 (Ortho) and antiLeu1 (Becton-Dickinson). Both antibodies have shown identical staining patterns in a large lymphoma material tested (own results).

Antibodies OKT3 (Ortho Pharmaceuticals) ${ }^{16}$ and $U C H T I^{17}$ both recognise a pan-T lymphocyte antigen which appears to be associated with the T lymphocyte antigen receptor.

Antibody Tü33, kindly donated by Dr Ziegler, is reactive with peripheral $\mathrm{T}$ lymphocytes, medullary thymocytes, but only weakly or partially with cortical thymocytes, indicating that it may be a differentiation marker within the $\mathrm{T}$ cell lineage (unpublished observations).

Antibody OKT6 (Ortho Pharmaceuticals) is reactive with antigens on thymus cortical cells (immature thymocytes), some interdigitating reticulum cells of the lymph node $T$ zone, and with the Langerhans' cells in squamous epithelium. ${ }^{16}$

Antibody OKT10 Ortho Pharmaceuticals) is reactive with early cortical thymocytes ${ }^{16}$; it is not a marker of immaturity or of cell lineage since plasmacytes are also stained strongly with this monoclonal antibody.

Antibodies OKT4 (Ortho Pharmaceuticals) and anti-Leu3a (Becton-Dickinson) react with the helper/inducer subtype of $T$ lymphocytes ${ }^{1618}$ and also with various macrophages, including histiocytosis X cells, and with epidermal Langerhans' cells (weakly). Staining with anti-Leu3a is usually stronger and more distinct than with OKT4.

Antibodies OKT8 (Ortho Pharmaceuticals) and Tü68 (Dr A Ziegler) recognise antigens on T lymphocytes of the suppressor/cytotoxic subsets. ${ }^{16}$ In our laboratory Tü68 has shown a staining pattern identical to OKT8.

Antibody Tü14 (Dr A Ziegler) is reactive with an undefined subpopulation of $\mathrm{T}$ lymphocytes. ${ }^{19}$ Among malignant lymphomas, the Tü14 marker is expressed particularly strongly by lymphoblasts of the convoluted cell type.

\footnotetext{
Myelomonocytic

Antibodies $3 C 4^{20}$ and Tü9 (Dr A Ziegler) react with cells of late neutrophilic granulopoiesis and with Hodgkin's and Reed-Sternberg cells but not with any other haematopoietic cells. ${ }^{81}$ Both react with the antigen also in formalin fixed paraffin embedded tissue sections.

Antibody OKM1 (Ortho Pharmaceuticals) is reactive with monocytes, macrophages, and myeloid cells. ${ }^{22}$
}

Common acute lymphoblastic antigen

Antibody J5 (Coulter Electronics) is reactive with the common acute lymphoblastic antigen. ${ }^{23}$

\section{$H L A-D R$ and related antigens}

Tü35 (Dr A Ziegler) ${ }^{24}$ and antihuman Ia (clone 7·2) (New England Nuclear) ${ }^{25}$ both recognise framework determinants of HLA-DR antigens.

Anti-Leu10 (Becton-Dickinson) is reactive with an allotypic determinant of the HLA-DC/DS locus (Dr F Brodsky, personal communication).

\section{$N K$ and $K$ cells}

Anti-Leu7 (Becton-Dickinson) reacts with medium and large lymphocytes containing azurophilic granules, some of which possess $T$ cell markers while others express monocytic markers. Leu7 positive cells possess $\mathrm{NK}$ and $\mathrm{K}$ function. ${ }^{26}$

\section{Polyclonal antibodies}

Rabbit antisera against human immunoglobulins $\alpha$, $\gamma, \mu$, and $\delta$ heavy chains and $\kappa$ and $\lambda$ light chains were obtained from Dakopatts a/s.

\section{IMMUNOPEROXIDASE STAINING}

The immunoperoxidase technique developed by Stein et $a^{\mathbf{8}}$ was used with minor modifications. Briefly, 7-8 $\mu \mathrm{m}$ frozen tissue sections were dried overnight at $37^{\circ} \mathrm{C}$, then fixed in acetone for $10 \mathrm{~min}$ followed by chloroform for $10 \mathrm{~min}$, both performed at room temperature. After incubation with monoclonal antibody for $1 \mathrm{~h}$, sections were rinsed in phosphate buffered saline (PBS) followed by a seccond incubation with rabbit antimouse immunoglobulin 1/100 (Dakopatts) for $30 \mathrm{~min}$. After another rinse in PBS a third incubation was performed with peroxidase conjugated swine antirabbit immunoglobulin 1/40 (Dakopatts) for $30 \mathrm{~min}$. Normal human serum was added during the second and third incubations to abolish cross reactivity with human immunoglobulin. Finally, sections were stained with diaminobenzidine and hydrogen peroxide for $10 \mathrm{~min}$. Mayer's haematoxylin was used for counterstaining, and slides were mounted in glycerol gelatin.

When staining with the rat monoclonal antibody $38 \cdot 13$, rabbit antirat immunoglobulin (Dakopatts) was used at a dilution of 1/100 for the second incubation.

\section{Results}

HISTOPATHOLOGY

Only four of the 24 non-B, non-T lymphomas which 
formed the basis of this study were classified morphologically as low grade malignant lymphomas (cases 1 to 4 in Table 2). As shown in Table 1, 7\% of all low grade malignant lymphomas were non-B, non- $T$ compared with $20 \%$ of the high grade lymphomas.

The four cases of low grade malignant lymphoma were morphologically typical cases of B-type chronic lymphatic leukaemia with pseudofollicular growth pattern (case 1), hairy cell leukaemia (case 2), mycosis fungoides (case 3), or malignant lymphoma of Lennert's type (case 4).

Seven of the 20 cases of high grade malignant lymphoma had been classified in a previous biopsy on morphological grounds as carcinoma or other non-haematopoietic tumour (cases $6,7,16,21,22$, and 24) or as haematopoietic neoplasia other than lymphoma (case 18). The true nature of these neoplasms was disclosed only after repeat biopsies performed for immunohistochemical investigation.

The morphological diagnosis of anaplastic centrocytic lymphoma was based on recently published criteria, ${ }^{1}$ whereas the remainder were based on criteria developed by Lennert et al. ${ }^{27}$ It is conceivable that the four cases of unclassifiable lymphomas of high grade malignancy (cases 21 to 24 inclusive) were also germinal centre tumours (anaplastic centrocytic and centroblastic lymphoma), but the degree of anaplasia and pleomorphism of the tumour cells prevented certain morphological classification.

\section{IMMUNOHISTOPATHOLOGY}

The phenotypic expressions of the 24 lymphomas are shown in Table 2. All cases except one stained with antibodies recognising either $\mathrm{B}$ or $\mathrm{T}$ cell antigens. An overlapping $B$ and $T$ phenotype was seen in one case (case 11) - a centroblastic lymphoma (B type) with aberrent expression of the T6 antigen.

\section{$B$ cell lymphomas}

The expression of $B$ cell antigens as defined with To15, anti-B1, anti-Leu12, and BA-1 was of particular interest since immunoglobulin was absent from all lymphomas in this series. Positive staining of the 18 B lymphomas was recorded as follows: To15 in 17 of 18 cases (94\%); anti-Leu 12 in 15 of 17 cases (88\%); anti-B1 in 14 of 18 cases $(78 \%)$; and BA-1 in 9 of 17 cases $(53 \%)$. No staining of $T$ lymphomas was obtained with To15, anti-Leu12, or anti-B1, but

Table 2 Phenotypic expression in 24 non-B, non-T lymphomas (SmIg, Clg, E receptor negative) after immunohistochemical labelling with 30 monoclonal antibodies

\begin{tabular}{|c|c|c|c|c|c|c|c|c|c|c|c|c|c|c|}
\hline Case & Histology ${ }^{*}$ & LE61 & $2 D 1$ & To15 & $B 1$ & Leu12 & $B A-1$ & $T \ddot{u} 1$ & $38 \cdot 13$ & $\begin{array}{l}\text { Lyt3/ } \\
O K T 11\end{array}$ & $\begin{array}{l}\text { Lyt2/ } \\
\text { Tü71 }\end{array}$ & $O K T 3$ & \multicolumn{2}{|c|}{ UCHT } \\
\hline 1 & B-CLL & - & $3+$ & $1+$ & $(+)$ & $3+$ & $3+$ & - & - & - & $3+$ & - & - & ᄀ \\
\hline 2 & HCL & - & $3+$ & $3+$ & $3+$ & $3+$ & - & - & - & - & - & - & - & $\frac{\overrightarrow{+}}{0}$ \\
\hline 3 & Myc fung & - & $3+$ & - & - & - & $3+$ & - & - & - & $3+$ & $1+$ & $3+$ & \\
\hline 4 & Lenn type & - & $3+$ & - & - & - & $3+$ & - & - & - & - & $3+$ & $3+$ & $\overrightarrow{0}$ \\
\hline 5 & $C C$,anapl & - & $3+$ & $1+$ & $3+$ & $2+$ & - & - & - & - & - & - & - & ? \\
\hline 6 & $"$ & - & $1+$ & $1+$ & $1+$ & - & - & - & - & - & - & - & - & g \\
\hline 7 & $"$ & - & $2+$ & $2+$ & $1+$ & $2+$ & $1+$ & - & $1+$ & - & - & - & - & 3 \\
\hline 8 & $"$ & - & $3+$ & - & $2+$ & $2+$ & $1+$ & - & - & - & - & - & - & i. \\
\hline 9 & " & - & $3+$ & $2+$ & $3+$ & $3+$ & $2+$ & $2+$ & - & - & - & - & - & 으 \\
\hline 10 & CB & - & $1+$ & $1+$ & $3+$ & $3+$ & $(+)$ & - & - & - & - & - & - & 3 \\
\hline 11 & $"$ & - & $1+$ & $2+$ & $1+$ & $3+$ & - & - & - & - & - & - & - & \\
\hline 12 & LB,BL & - & $3+$ & $3+$ & $3+$ & $3+$ & - & - & - & - & - & - & - & 옥 \\
\hline 13 & LB, con & - & $3+$ & - & - & - & $(+)$ & - & - & - & $3+$ & - & $3+$ & \\
\hline 14 & & - & $3+$ & - & - & - & - & - & - & - & - & $1+$ & $3+$ & \\
\hline 15 & LB,uncon & - & $2+$ & - & - & - & - & - & - & - & - & - & - & 兰. \\
\hline 16 & LB, unclass & - & $3+$ & $3+$ & - & ND & ND & - & - & - & - & - & ND & $\bar{N}$ \\
\hline 17 & $"$ & - & $3+$ & $2+$ & - & $2+$ & $3+$ & - & - & - & - & - & - & (ా \\
\hline 18 & ", & - & $3+$ & - & - & - & - & - & - & - & - & - & - & \\
\hline 19 & $"$ & - & $+1-$ & $(+)$ & $1+$ & $2+$ & $1+$ & - & $1+$ & - & - & - & - & $\mathcal{n}$ \\
\hline 20 & IB & - & $3+$ & $2+$ & - & $2+$ & - & - & - & - & - & - & - & N \\
\hline 21 & ML,hg. & - & $3+$ & $2+$ & $1+$ & $3+$ & $1+$ & 一 & - & - & - & - & - & \\
\hline 22 & " & - & $3+$ & $3+$ & $3+$ & $3+$ & - & - & - & - & - & - & - & $\underset{\gamma}{\sigma}$ \\
\hline 23 & 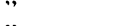 & - & $2+$ & $2+$ & - & - & $1+$ & - & - & - & - & - & - & 8 \\
\hline 24 & "’ & - & $2+$ & $2+$ & $3+$ & $3+$ & - & - & - & - & - & - & - & $\underline{E}$ \\
\hline
\end{tabular}

Abbreviations: $\mathrm{B}-\mathrm{CLL}=$ lymphoma corresponding to $\mathrm{B}$ type chronic lymphatic leukaemia; $\mathrm{CB}=$ malignant lymphoma, centroblastic type; $\mathscr{E}$ anapl = malignant lymphoma, anaplastic centrocytic type; $\mathbf{C I g}=$ cytoplasmic Ig; $\mathrm{E}$ receptor $=$ sheep erythrocyte receptor; $\mathrm{HCL}=\mathrm{hairy}$ eell leukaemia; IB = malignant lymphoma, immunoblastic type; LB,BL = malignant lymphoma, lymphoblastic, Burkitt's type; LB, con = malignont lymphoma, lymphoblastic, convoluted type; LB, unclass = malignant lymphoma, lymphoblastic, unclassified; LB uncon = malignant lymphoma, lymphoblastic, non-convoluted type; Lenn type = malignant lymphoma, Lennert's type; ML, hg = malignant lymphoma, high grade, not otheru仿e specified; myc fung = mycosis fungoides; $\mathrm{ND}=$ not determined; $\mathrm{SmIg}=$ surface membrane Ig. Degree of staining: $-=$ no staining; $(+)=$ very weak; $1+=$ weak; $2+=$ moderate intensity; $3+=$ strong staining; $+1-=$ partial staining winh
occurrence of positive and negative tumour cells but with predominance of positive tumour cells.

${ }^{*}$ Histological classification of the non-B, non-T lymphomas comprises the final diagnosis in which all available information was included. 
BA-1 also stained three of six T lymphomas. It may be concluded that the B cell specificity of the monoclonal antibodies To15, anti-Leu12, and anti-B1 is high whereas BA-1 is not B cell specific.

The intensity of specific reactions in relation to background staining was high for anti-Leu12 and To15 but less satisfactory for anti-B1, mainly because of the staining of macrophages by this antibody.

The antigens detectable by monoclonal antibodies To15, anti-B1, and anti-Leu12 were clearly different since case 6 reacted with To15 and anti-B1 but not anti-Leu12, case 8 reacted with anti-B1 and anti-Leu12 but not To15, and cases 17 and 20 reacted with To15 and anti-Leu 12 but not with anti-B1.

The $B$ cell antigens with a restricted distribution detected with the monoclonal antibodies Tü1 and 38.13 were of no particular value in this study since they were present on only a few B cell neoplasms (Table 2).

\section{$T$ cell lymphomas}

Whereas most of the $18 \mathrm{~B}$ cell lymphomas were stained by all or most of the pan-B cell antibodies, the $6 \mathrm{~T}$ cell lymphomas showed variable reactions with the $T$ cell antibodies. The pan- $T$ lymphocyte antibodies OKT3, UCHT1, anti-Lyt2, Tü71, and Tü33 stained only $3,4,2,2$, and 3 of the $6 \mathrm{~T}$ lymphomas, respectively (Table 2 ). The two antibodies against the $67000 \mathrm{MW}$ T cell marker (anti-Lyt2 and Tü71) showed the same staining pattern, but the two antibodies against the 19-29 000 MW T cell marker (OKT3 and UCHT1) differed clearly in the reactions, as seen in case 13, which showed strong expression of UCHT1 but was T3 negative.

In general, the sheep erythrocyte receptor negative $\mathrm{T}$ lymphomas showed aberrent phenotypes. One case (case 18), a cutaneous lymphoblastic lymphoma, unclassified, expressed only the $T$ helper cell associated antigens T4 and Leu3a, and was devoid of other T cell antigens. The case of Lennert's lymphoma (case 4), supposed to represent a proliferation of peripheral T lymphocytes, expressed the T3 antigen and lacked the T6 antigen, but was devoid of both $\mathrm{T}$ helper and $\mathrm{T}$ suppressor cell associated antigens.

It is of interest that none of the four $\mathrm{T}$ lymphoblastic lymphomas expressed the T6 antigen, a marker commonly present on immature $T$ cell neoplasms. In line with our previous observations, however, the two cases of lymphoblastic lymphoma of

Table 2 continued

\begin{tabular}{|c|c|c|c|c|c|c|c|c|c|c|c|c|c|c|c|}
\hline Tü33 & OKT6 & OKT10 & $O K T 4$ & Leu3a & $\begin{array}{l}\text { OKT8I } \\
\text { Tü68 }\end{array}$ & Tü14 & $3 C 4$ & $T \ddot{Q} 9$ & $O K M I$ & $J 5$ & Tü35 & anti-Ia & Leulo & Leu7 & Phenotype \\
\hline- & - & - & - & - & - & - & - & - & - & - & $3+$ & $2+$ & $3+$ & - & B \\
\hline- & - & - & - & - & - & - & - & - & - & - & $3+$ & $3+$ & $3+$ & - & B \\
\hline $2+$ & - & - & $3+$ & $2+$ & - & - & - & - & - & - & - & - & - & - & $\mathrm{T}$ \\
\hline $3+$ & - & $3+$ & - & - & - & - & - & - & - & - & - & - & - & - & $\mathbf{T}$ \\
\hline- & - & - & - & - & - & - & - & - & - & $1+$ & $3+$ & $2+$ & $2+$ & - & B \\
\hline- & - & - & - & - & - & - & - & - & - & - & $3+$ & $3+$ & $3+$ & - & $\overline{\mathbf{B}}$ \\
\hline- & - & - & - & - & - & - & - & - & - & - & $3+$ & $3+$ & $3+$ & - & B \\
\hline- & - & - & - & - & - & - & - & - & - & - & $3+$ & $3+$ & $3+$ & - & B \\
\hline- & - & - & - & - & - & - & - & - & - & - & $2+$ & $2+$ & $2+$ & - & B \\
\hline- & - & - & - & - & - & - & - & - & - & $(+)$ & - & - & - & - & B \\
\hline- & $3+$ & - & - & - & - & - & - & - & - & - & $3+$ & $3+$ & $3+$ & - & B \\
\hline- & - & $2+$ & - & - & - & - & - & - & - & $2+$ & $3+$ & $3+$ & $3+$ & - & $\overline{\mathbf{B}}$ \\
\hline $2+$ & - & $2+$ & - & - & - & $3+$ & - & - & - & - & $1+$ & $1+$ & - & - & $\bar{T}$ \\
\hline- & - & $3+$ & - & - & - & $3+$ & - & - & - & - & - & - & - & - & $\mathbf{T}$ \\
\hline- & - & $1+$ & $(+)$ & $3+$ & - & - & - & - & - & - & $3+$ & $3+$ & $2+$ & - & $\mathbf{T}$ \\
\hline- & - & - & - & - & - & - & - & - & - & - & $3+$ & $3+$ & ND & - & B \\
\hline- & - & $3+$ & - & - & - & - & - & - & - & $3+$ & $3+$ & $3+$ & - & - & B \\
\hline- & - & - & $1+$ & $2+$ & - & - & - & - & - & - & $3+$ & $3+$ & - & - & $\bar{T}$ \\
\hline- & - & - & - & - & - & - & - & - & - & $3+$ & $2+$ & $2+$ & $1+$ & - & $\dot{\mathbf{B}}$ \\
\hline- & - & - & - & - & - & - & - & - & - & - & $2+$ & $3+$ & $2+$ & - & B \\
\hline- & - & - & - & - & - & - & - & - & - & - & - & $3+$ & $3+$ & - & B \\
\hline- & - & - & - & - & - & - & - & - & - & - & - & - & - & - & B \\
\hline- & - & - & - & - & - & - & - & - & - & - & $3+$ & $2+$ & $3+$ & - & B \\
\hline- & - & - & - & - & - & - & - & - & - & - & $3+$ & $3+$ & $3+$ & - & B \\
\hline
\end{tabular}



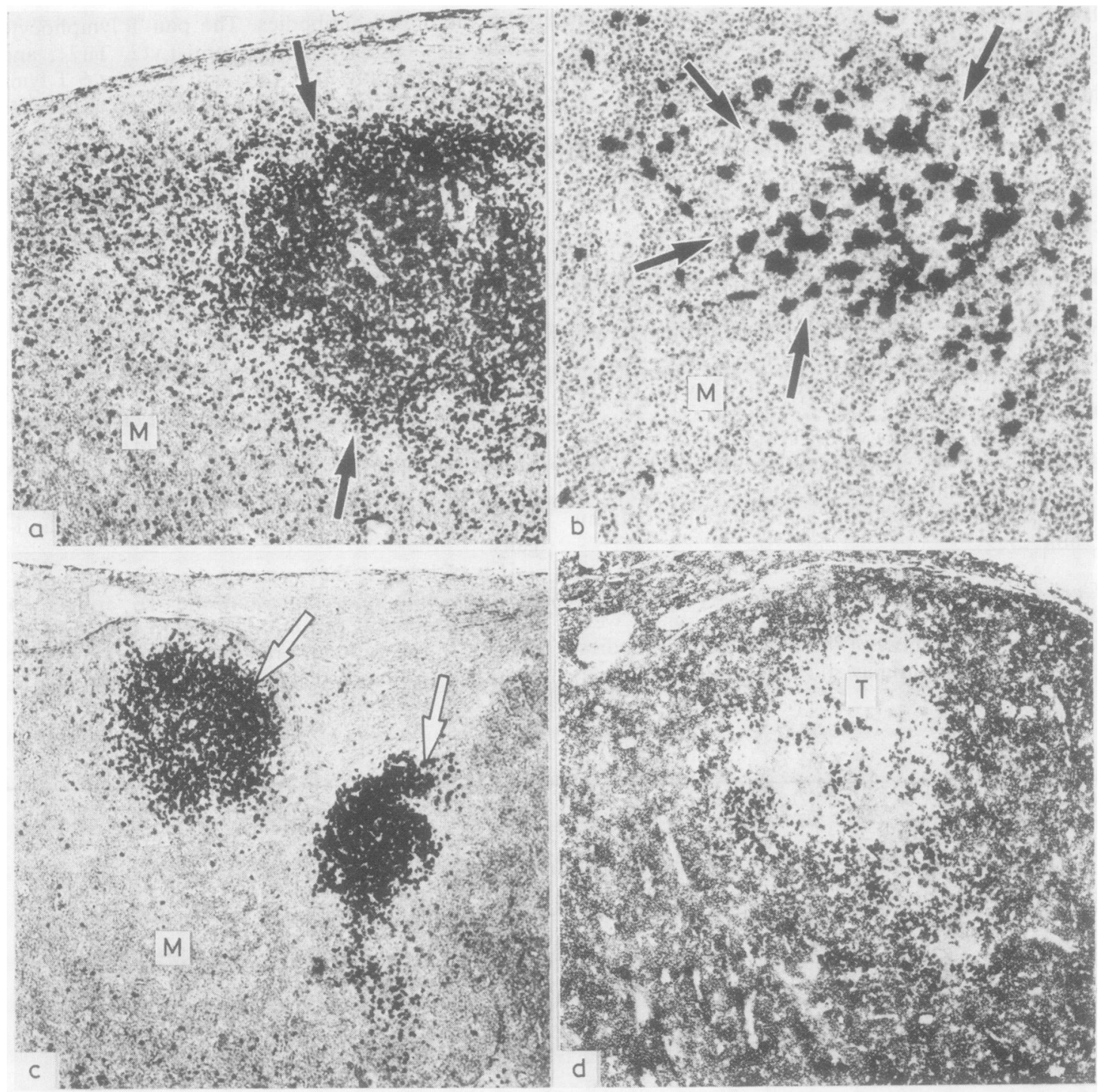

Illustrations from case 19 (Table 2: pre-pre-B type lymphoblastic lymphoma). (a) Staining of a lymph node cryostat section for $T$ cell antigens (monoclonal antibody Tü71) shows a residual $T$ zone (arrows), scattered non-neoplastic $T$ cells in the malignant infiltrate $(M)$, and no staining of the neoplastic cells $(\times 50)$. (b) Staining of an adjacent section with OKT6 shows positively stained interdigitating reticulum cells in the preserved $T$ cell area (arrows) but no staining of the malignant infiltrate $(M)(\times 130)$. (c) Staining for IgM discloses preserved primary follicles (white arrows) but no staining of the malignant infiltrate $(M)(\times 50)$. (d) Staining for common acute lymphoblastic antigen shows strong membrane staining of infiltrating lymphoblasts but no staining of preserved $T$ cell area $(T)(\times 50)$.

convoluted cell type both expressed the Tü14 antigen strongly. The case of mycosis fungoides showed a near normal $\mathrm{T}$ helper cell phenotype except that sheep erythrocyte receptors were not expressed.

\section{Lymphoblastic lymphoma}

The histological group of lymphoblastic lymphoma, unclassified, included both $B$ and $T$ lymphocyte phenotypes. Two of the $\mathrm{B}$ derived lymphoblastic lymphomas (cases 17 and 19) occurred in children who later developed leukaemia (FAB type L1). Both cases conformed phenotypically to the prepre-B cell type of lymphoblastic lymphoma (Ig negative; To15, Leu12, J5, HLA-DR positive). In 
case 19 the initial pattern of tumour growth was that of multiple skin tumours.

\section{Advantage of immunohistological typing}

Case 19 provided one among several examples of the advantages offered by immunohistological phenotyping as opposed to the use of cell suspensions. Attempts to phenotype this neoplasm using cell suspensions from skin biopsies were inconclusive owing to a low yield of tumour cells, whereas the results obtained when tissue was stained with monoclonal antibodies by the immunohistological method were easily interpretable. Moreover, two lymph node biopsies showed abnormal but inconclusive phenotypes in cell suspensions since almost half of the lymph node constituents were residual normal components. With immunohistological staining of cryostat sections, however, the zonal distribution in malignant and residual benign areas was easily appreciated and the phenotype of the tumour cells could be assessed accurately (Figure).

\section{Miscellaneous antibodies}

None of the lymphomas showed any staining with antibodies against granulocytes, monocytes, or killer and natural killer cells (3C4, Tü9, OKM1, antiLeu7). HLA-DR antigen was expressed by the tumour cells in 16 of the 18 lymphomas which could be characterised as B cell derived, but was also expressed in three of the six $\mathrm{T}$ lymphomas.

\section{Discussion}

A major aim of this study was to investigate the histogenesis of lymphomas that are unclassifiable when phenotyped using conventional methodsthat is cases which do not express surface membrane immunoglobulin, cytoplasmic immunoglobulin, or sheep erythrocyte receptor.' For this purpose we performed immunohistochemical staining with an extensive panel of monoclonal antibodies in 24 cases from which frozen, unfixed biopsy material was available.

The results of our study indicated that all of these non-B, non- $T$ lymphomas expressed antigens associated with either the $\mathrm{B}$ or the $\mathrm{T}$ cell lineage; only one lymphoma (case 11) was exceptional in that it expressed both B and T cell markers. Since the only $\mathrm{T}$ cell antigen expressed was T6, however, and since the B cell antigens detectable with To15, anti-B1, and anti-Leu12 were all expressed in this case (the morphology of which was typical of a diffuse centroblastic lymphoma), we considered this neoplasm a true B lymphoma. In this context it may be noted that OKT6 is known to react with several types of non-T cells - that is, Langerhans' cells, interdigitating reticulum cells, and even neuroblastoma cells. ${ }^{28}$

The three pan-B cell antibodies To15, anti-B1, and anti-Leu 12 all appeared highly specific and reliable in detecting B cell lymphomas, but the simultaneous use of each of these monoclonal antibodies was necessary to detect the B cell nature of each of the 18 lymphomas.

A wider panel of $T$ cell associated antibodies proved necessary to detect the six lymphomas ultimately phenotyped as $\mathrm{T}$ derived since each of the pan-T cell antibodies used (OKT3, UCHT1, antiLyt2, Tü71, and Tü33) reacted with only some of these neoplasms.

To15 and UCHT1 were the single most reliable antibodies for detecting B and $\mathrm{T}$ cell neoplasms, respectively.

An additional feature of the $T$ cell lymphomas in the present study deserves comment. At present, no commonly recognised immunological marker analogous to the immunoglobulin light chain restriction of B lymphomas allows the monoclonality of $\mathrm{T}$ cell proliferations to be shown. However, the uniform expression of aberrent phenotypes by cells of such $\mathrm{T}$ cell proliferations constitutes an indirect way of identifying their neoplastic nature.

In conclusion, all non- $\mathrm{B}$, non- $\mathrm{T}$ lymphomas of our study could be referred to either the $B$ or the $T$ lymphocyte lineage after immunohistochemical investigation with an extensive panel of monoclonal antibodies. This suggests that true non- $B$, non- $T$ lymphomas are rare, if not non-existent. This investigation also shows the potency of monoclonal antibodies as tools for taxonomic and diagnostic lymphoma work.

We are grateful to Ms Anette Fuglsang and Ms Birthe Hermansen for technical assistance, to $\mathrm{Mr} \mathrm{S}$ Shapiro for photographic work, and to Ms Anne Holmehave for typing the manuscript. This study was supported by the Danish Cancer Society (grant no 20/80), partly by the Anders Hasselbalch Foundation Against Leukaemia, the Leukaemia Research Fund, and the Deutsche Forschungsgemeinschaft (SFB 111, CL1).

\section{References}

' Pallesen G, Madsen M, Schifter T. Immune marker expression in 53 lymphomas of high-grade malignancy. Histopathology 1983;7:841-57.

2 Van Heerde PV, Feltkamp CA, Feltkamp-Vroom TM, Koudstall J, van Unnik JAM. Non-Hodgkin's lymphoma. Immunohistochemical and electron microscopical findings in relation to light microscopy. A study of 74 cases. Cancer 1980; 46:2210-20.

${ }^{3}$ Warnke R, Miller R, Grogan T, Pederson M, Dilley J, Levy R. Immunologic phenotype in 30 patients with diffuse large-cell lymphoma. N Engl J Med 1980;303:293-300. 
${ }^{4}$ Rudders RA, Ahl ET, DeLellis RA. Surface marker and histopathologic correlation with long-term survival in advanced large-cell non Hodgkin's lymphoma. Cancer 1981;47:132935.

${ }^{5}$ Lane EB. Monoclonal antibodies provide specific intramolecular markers for the study of epithelial tonofilament organization. J Cell Biol 1982;92:665-73.

- Pizzolo G, Sloane J, Beverley P, et al. Differential diagnosis of malignant lymphoma and nonlymphoid tumors using monoclonal anti-leucocyte antibody. Cancer 1980;46:2640-7.

' Gatter KC, Abdulaziz Z, Beverley P, et al. Use of monoclonal antibodies for the histopathological diagnosis of human malignancy. J Clin Pathol 1982;35: 1253-67.

* Stein H, Gerdes J, Schwab U, et al. Identification of Hodgkin and Sternberg-Reed cells as a unique cell type derived from a newly-detected small-cell population. Int $J$ Cancer 1982;30:445-59.

' Stashenko P, Nadler LM, Hardy R, Schlossman SF. Characterization of a human B lymphocyte specific antigen.J Immunol 1980;125: 1678-85.

${ }^{10}$ Abramson CS, Kersey JH, LeBien TW. A monoclonal antibody (BA-1) reactive with cells of human B lymphocyte lineage. J Immunol 1981;126:83-8.

"Ziegler A, Stein H, Müller C, Wernet P. Tül: A monoclonal antibody defining a $B$ cell subpopulation-usefulness for the classification of non-Hodgkin's lymphomas. In: Knapp W, ed. Leukemia markers. London: Academic Press, 1981:113-6.

${ }^{12}$ Wiels J, Fellous M, Tursz T. Monoclonal antibody against a Burkitt lymphoma-associated antigen. Proc Natl Acad Sci USA 1981;78:6485-8.

${ }^{13}$ Kamoun M, Martin PJ, Hansen JA, Brown MA, Siadak AW, Nowinski RC. Identification of a human T lymphocyte surface protein associated with the E-rosette receptor. J Exp Med 1981;153:207-12.

${ }^{14}$ Verbi W, Greaves MF, Schneider C, et al. Monoclonal antibodies OKT11 and OKT11A have pan-T reactivity and block sheep erythrocyte "receptors". Eur J Immunol 1982;12:81-6.

is Martin PJ, Hansen JA, Nowinski RC, Brown MA. A new human T-cell differentiation antigen: Unexpected expression on chronic lymphocytic leukemia cells. Immunogenetics 1980; 11:429-39.

${ }^{10}$ Reinherz EL, Kung PC, Goldstein G, Levey RH, Schlossman SF. Discrete stages of human intrathymic differentiation: Analysis of normal thymocytes and leukemic lymphoblasts of T-cell lineage. Proc Natl Acad Sci USA 1980;77:1588-92.

${ }^{17}$ Beverley PCL. Callard RE. Distinctive functional characteristics of human " $T$ " lymphocytes defined by $E$ rosetting or a mono- clonal anti-T cell antibody. Eur J Immunol 1981;11:329-34.

${ }^{18}$ Evans RL, Wall DW, Platsoucas CD, et al. Thymus-dependent membrane antigens in man: Inhibition of cell-mediated lympholysis by monoclonal antibodies to $\mathrm{TH}_{2}$ antigen. Proc Natl Acad Sci USA 1981;78:544-8.

19 Ziegler A, Uchanska-Ziegler B, Rosenfelder G, Braun DG, Wernet $P$. Heterogeneity of established human hematopoietic cell lines: Surface antigens detected by monoclonal antibodies and glycosphingolipid patterns. In: Knapp W, ed. Leukemia markers. London: Academic Press, 1981:317-20.

${ }^{20}$ Schienle HW, Stein H, Müller-Ruchholtz W. Neutrophil granulocytic cell antigen defined by a monoclonal antibodyits distribution within normal haemic and non-haemic tissue. $J$ Clin Pathol 1982;35:959-66.

${ }^{21}$ Uchańska-Ziegler B, Wernet P, Ziegler A. Monoclonal antibodies against human lymphoid and myeloid antigens: AMML cells as immunogen. In: Knapp W, ed. Leukemia markers. London: Academic Press, 1981:243-6.

${ }^{22}$ Breard J, Reinherz EL, Kung PC, Goldstein G, Schlossman SF. A monoclonal antibody reactive with human peripheral blood monocytes. J Immunol 1980; 124:1943-8.

${ }^{23}$ Ritz J, Nadler LM, Bhan AK, Notis-McConarty J, Pesando JM, Schlossman SF. Expression of common acute lymphoblastic leukemia antigen (CALLA) by lymphomas of B-cell and T-cell lineage. Blood 1981:58:648-52.

${ }^{24}$ Ziegler A, Uchańska-Ziegler B, Zeuthen J, Wernet P. HLA antigen expression at the single cell level on a K562 $\times$ B cell hybrid: An analysis with monoclonal antibodies using bacterial binding assays. Somatic Cell Genetics 1982;8:775-89.

${ }^{25}$ Hansen JA, Martin JP, Nowinski RC. Monoclonal antibodies identifying a novel T-Cell antigen and Ia antigens of human lymphocytes. Immunogenetics $1980 ; 10: 247-60$.

${ }^{20}$ Abo T, Balch CM. A differentiation antigen of human NK and $\mathrm{K}$ cells identified by a monoclonal antibody (HNK-1). J Immunol 1981;127:1024-9.

${ }^{27}$ Lennert K, Mohri N, Stein H, Kaiserling E, Müller-Hermelink HK. Malignant lymphomas other than Hodgkin's disease. Berlin-Heidelberg-New York: Springer-Verlag, 1978.

${ }^{2 *}$ Greaves M, Delia D, Sutherland R, et al. Expression of the OKT monoclonal antibody defined antigenic determinants in malignancy. Int J Immunopharmacol 1981;3:283-300.

Requests for reprints to: Dr G Pallesen, University Institute of Pathology, University of Aarhus, Kommunehospitalet, DK-8000 Aarhus C, Denmark. 